\title{
Generic Hybridity in Athenian Tragedy
}

\author{
Naomi Weiss*
}

Though we often view tragedy primarily in terms of the character and actions of its protagonists, it was, first and foremost, a choral genre. Even Aristotle, who in the Poetics largely avoids discussion of the chorus altogether, tells us that

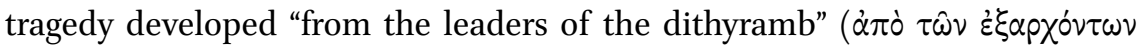

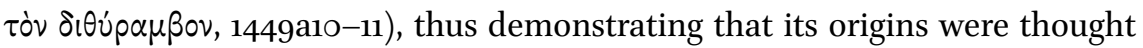
to be choral. In his Laws Plato, who, unlike Aristotle, had grown up in Athens, presumably regularly attending the theater and even participating in various choruses himself, clearly views tragedy in terms of choral song and dance-a combination called choreia, which the Athenian Stranger presents as vital to the city's social, ethical, and physical fabric. The choral nature of this genre also becomes evident when we consider how many tragedies (especially those of Aeschylus) are named after their choruses, and how much of a tragedy could consist in choreia: in Aeschylus' Supplices, for example, the chorus sings for more than half the play; in Agamemnon and Choephoroi for just under half. Though later tragedy tends to include less choral song, on average it still occupies at least 15 percent of Sophoclean and Euripidean drama. ${ }^{1}$

The predominance of choreia in Aeschylus' surviving plays suggests not only that it played a big part in early tragedy, but that early tragedy was by its very nature an amalgamation of different types of choral song, interspersed with actors' dialogue (and occasionally actors' song). Supplices, with its high proportion of choreia, demonstrates this mix well. Initially lament seems to dominate the play, as the maidens mourn their plight and seek protection in Argosindeed, in their parodos they characterize themselves as continuously lament-

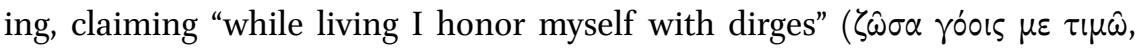

* Many thanks to the participants of the conference on lyric genres at Berkeley for their stimulating comments on the initial version of this paper, and to my coeditors for the astute and helpful feedback that led to its final form.

1 These figures include recitative within the category of choral song. For percentages of song (choral and solo) in the surviving plays of Sophocles and Euripides, see Csapo 1999-200o: 410-411. On tragedy as a choral event see Bacon 1994-1995; Gagné and Hopman 2013a: 1922. Kowalzig 2007a (esp. 225-226) emphasizes that the Athenians thought of their dramatic contests as the "choroi of Dionysus." 
116). As Laura Swift has recently shown, however, the chorus' songs also evoke parthenaic and hymeneal performances, especially in the exodos, which, like some marriage songs, is split between two choruses, the Danaid maidens and most likely the male attendants, and is full of references to both marriage and virginity. ${ }^{2}$ They can resemble hymns too, such as when the maidens sing to Zeus in the second stasimon, addressing him as "King of kings, most blessed of the

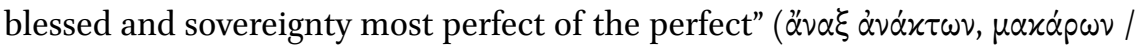

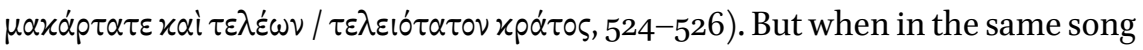
they describe the maddened wanderings of Io through Asia and her arrival in Egypt, where she bore to Zeus their ancestor, Epaphus, they evoke a narrative style more akin to the dithyramb; indeed, Bacchylides makes this very story the subject of his fifth dithyramb. ${ }^{3}$ However, even while we should recognize that these different sorts of choral performance are present in the tragedy, any attempt to label each one according to the particular "nondramatic" lyric genre that it evokes is ultimately unsatisfying, for it is the complex mix of choral styles that makes up the one tragic play. If we separate out and try to categorize the generic strands of a drama we run the risk of missing the all-encompassing capacity of tragedy - its ability to embrace, combine, and transform multiple lyric genres. ${ }^{4}$

Tragedy, then, is a hybrid genre. We might, to borrow Richard Martin's influential term for epic, even call it a "super-genre," one which includes and appropriates a wide variety of lyric subgenres (and nonlyric too, such as oratory), integrating them within the dramatic narrative of a play. ${ }^{5}$ These lyric subgenres are "nondramatic" in the sense that they concern discrete performances of choreia that do not form part of larger dramatic narratives featuring a group of actors assuming a variety of roles. Even the dithyramb, which was performed in the same theatrical space as "dramatic" genres, is still in this way distinct from tragedy, comedy, and satyr play. One way to explore the hybridity of tragedy would be to track allusions to nondramatic lyric through linguistic markers and particular types of imagery in a systematic way, separating out one genre

2 Swift 2010: 280-29o. She argues convincingly against the traditional reading of this song, which assigns the second chorus to the group of female attendants named at Supp. 977-979; cf. McCall 1976.

3 Bacch. 19 (Io, for the Athenians). On this dithyramb's relationship to tragedy, specifically Supplices, see esp. Maehler 2004: 206-209; Battezzato 2013: 96. In addition, the story of Io somewhat resembles that of Dionysus' birth to Semele (also impregnated by Zeus), which seems to have been a frequent subject within the dithyrambic genre, as Timotheus' Birthpangs of Semele in particular attests (fr. 792; see too Pind. fr. 7ob. 29-32; Eur. Bacch. 88-106).

4 My approach here therefore contrasts with that of Swift 2010.

5 Martin 2005: 17. 
from another: parthenaic from hymenaeal, dithyrambic from paeanic, epinician from lament, and so on. ${ }^{6}$ Instead, however, I want to focus here on the malleability of lyric genres within the context of the theater, and on the ways in which generic allusion and interaction might work in performance. My aim is in part to come to a better understanding of what tragedy itself is as a genre, and of how ancient practitioners and theorists of tragedy promoted and played with ideas of what sort of genre it was and how as a genre it developed. But I am primarily concerned with the question of how useful the notion of distinct lyric genres ultimately is for our appreciation of what tragedy can achieve in performance. I suggest that it is useful, perhaps even vital, since the evocation of nondramatic lyric genres within tragic choreia can guide the audience's reception of the dramatic action, and so help to shape the entire plot of a play. But at the same time we must be conscious of how these evocations of genre interact with others, creating a musical narrative in tandem with the dramatic one through the combination of different types of song.

\section{Turning to Lament: Euripides' Heracles and Sophocles' Trachiniae}

Most extant fifth-century tragedies exhibit a conflation or juxtaposition of different choral genres, and often a transition from one to another can complement or even anticipate the direction of the dramatic narrative. This transition is typically to or from lament: from more joyful forms of song (or combinations of song) to lament or vice-versa, depending on the outcome of the plot. Two powerful examples of the former type of musical structure are Euripides' Heracles and Sophocles' Trachiniae, both of which mark the reversal of Heracles' fortunes through a shift from the jubilant conflation of celebratory forms of mousike (music, song, dance) to lament and then, ultimately, to choral silence. In the second stasimon of Euripides' play, after lamenting old age and praising youth, the chorus explicitly points to its own generic mixing as it celebrates Heracles' achievements:

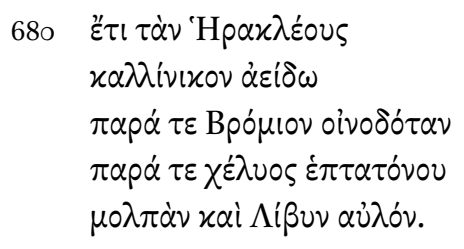

6 As in Swift 2010. 


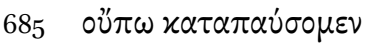

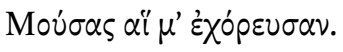

$\pi \alpha \iota \hat{\alpha} \nu \alpha \mu \dot{\varepsilon} \nu \Delta \eta \lambda ı \dot{\alpha} \delta \varepsilon \varsigma$

$\langle\nu \alpha \hat{\omega} v\rangle \dot{v} \mu \nu 0 \hat{\sigma} \sigma^{\prime} \dot{\alpha} \mu \varphi i \pi \dot{u} \lambda \alpha \varsigma$

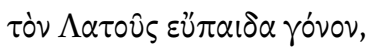

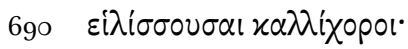

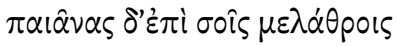

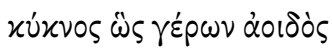

$\pi \circ \lambda ı \hat{\alpha} \nu \dot{\varepsilon} x \gamma \varepsilon v \dot{v} \omega \nu$

$x \varepsilon \lambda \alpha \delta \dot{\eta} \sigma \omega$.

Still I sing the kallinikos 〈song of Heracles, both in the company of Bromios the wine-giver and in the company of the music of the sevenstringed tortoise-shell and the Libyan aulos. Not yet will we put an end to the Muses, who set us dancing.

The Delian Maidens sing a paean around the gates 〈of the temples〉 for the noble child of Leto, whirling, beautiful choruses; so paeans upon your halls I shall cry out like a swan, aged singer, from my grey cheeks.

EUR. $H F$ 68o-694

This polyphonic image is an incongruous one. Here we have old men claiming to sing both an epinician song of victory (kallinikos) and Dionysiac mousike ("in the company of Bromios"), and to combine two instruments, the kithara and aulos, in "a very rare tragic image of harmonious union."7 They encourage the audience to see and hear them as a maiden chorus, like the Muses or the Delian Maidens, yet outside tragedy the paean, the song that they then claim to sing, would typically be performed by men. ${ }^{8}$ Although there are examples within Athenian tragedy of female choruses performing paeans, the muddling of genders here seems to be deliberately marked, pointing to the unlikelihood of this group of old Thebans being able to sing and dance as it claims to.

7 Wilson 1999-200o: 435. On the generic hybridity here, see also Carey 2012: 29-30. Other scholars have tended to focus almost exclusively on the epinician character of this ode: see Parry 1965; Rehm 1996-1997: 53; Swift 2010: 129-131.

8 On this contradictory image, see Henrichs 1996a: 59-6o. On the gender of paeanic performers, see Calame 1997a: 76-79; Rutherford 2001: 58-59; Swift 2010: 64-65. For examples of female choruses performing paeans in tragedy, see Aesch. Cho. 149-151; Soph. Trach. 205-224; Eur. Hel.174-178, IA 1475-1531. On this phenomenon see Rutherford 1994-1995: 120, 2001:113; Weiss 2014: 125-126. 
This unlikelihood becomes even clearer when the chorus then depicts itself as a swan, singing from grey cheeks: not only does this image underscore the men's age, it also introduces a note of lament, since the swan typically mourns its own impending death. ${ }^{9}$ The extreme mixing of genres here undercuts the chorus' celebratory festivity, as the overload of different forms of choral performance — or at least verbal allusions to these different forms—ends with a reference to lament.

Though it appears celebratory, then, the ode foreshadows with this note of unease the interruption of the chorus' next, even more exuberant song by the appearance of Iris and Lyssa, who herald the bloody reversal in Heracles' fortune. This reversal is marked, as PeterWilson has shown, by an emphasis on the madness brought on by Dionysiac mousike, of which the aulos, the very instrument being played in the theater, is the main agent: Lyssa even declares to the chorus that she will "pipe [it] down with fear" ( $\alpha \alpha \tau \alpha \nu \lambda \eta \dot{ } \sigma \omega \varphi \hat{o} \beta \omega, 871) .{ }^{10}$ Following the messenger's account of Heracles' murder of his wife and children, lament then takes over, though the chorus questions even this as an appropriate form of song given the enormity of the hero's suffering:

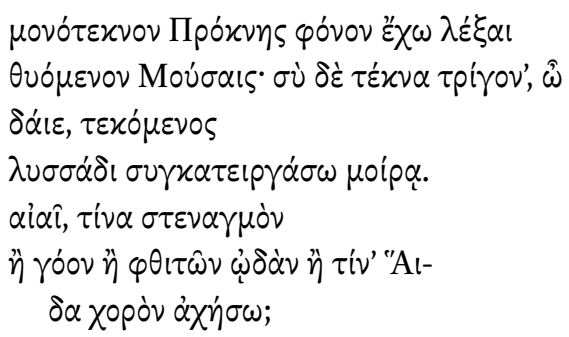

I can tell of Procne's murder of her only child, sacrificed for the Muses. But you, wretched man, sired three children and killed them all together by your raging mad fate. Aiai, what groan or wail or song for the dead or what chorus of Hades shall I cry out?

EUR. $H F$ 1021-1027

After an antiphonal exchange of mourning with Amphitryon, the chorus is then virtually silent for the last third of the play, as the focus turns instead to the exchange between the old man, Heracles, and Theseus.

9 Cf. Aesch. Ag. 1444-1446; Pl. Phd. 84e-85a; Arist. Hist. an. 615b2-6. At Eur. El. 151-156 Electra compares herself to a swan in mourning her father's death, which she seems to equate with her own. On the bird's association with self-lament see Arnott 2007: 123.

Wilson 1999-200o: 435-439. 
The musical structure of Sophocles' Trachiniae is very similar to that of Euripides' play: multiple lyric genres are embedded within the chorus' expressions of premature jubilation, and these transition into markedly different forms after Deianeira unwittingly poisons Heracles. In the first stasimon, following the news of the hero's imminent arrival, the chorus excitedly combines different types of song, and in doing so refers directly to its own performance:11

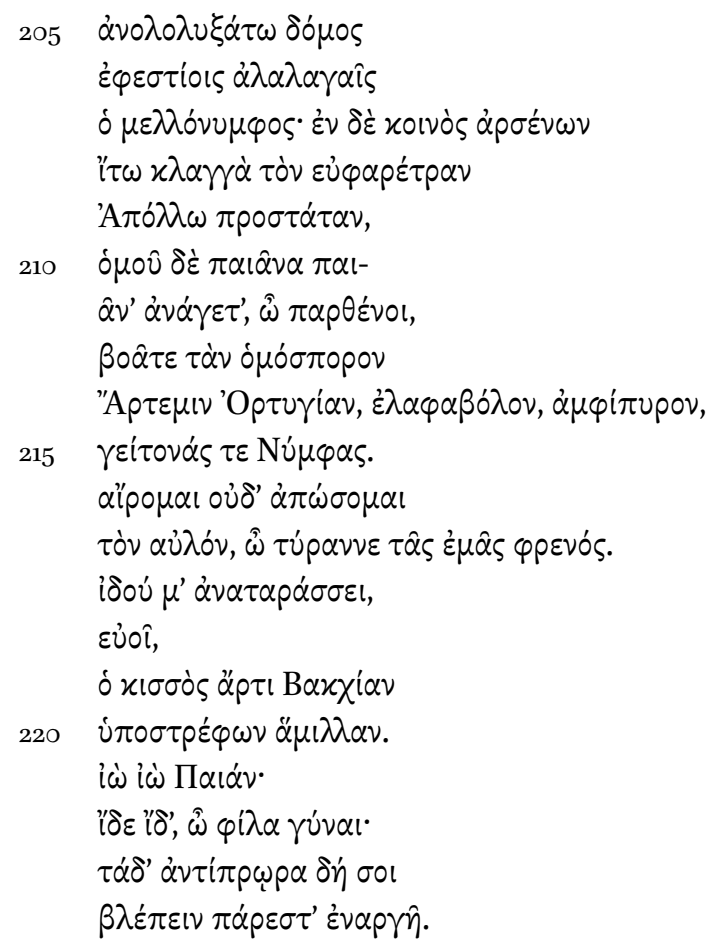

Let the house raise a shout of ololuge, with shouts of alalai by the hearth, [the house] that is to be united in marriage. And let the collective cry of men go up to the one of the fair quiver, Apollo the protector, and you, O maidens, together raise up the paean, the paean, call upon his sister Artemis the Ortygian, deer-shooter, bearer of the double torch, and the neighboring nymphs. I'm lifted up and will not reject the aulos, O tyrant of my mind. Look, the ivy shakes me up, euoi, turning me round just now in the Bacchic contest. Io io Paian! Look, look, O dear lady: You can see these things clearly, right in front of you. (Soph. Trach. 205-224)

\footnotetext{
11 On the generic "fusion" at work in this ode, see also Foster's paper in this volume.
} 
We cannot generically classify this ode, or at least not simply. As both Albert Henrichs and Timothy Power have shown, it includes elements of hymenaeal, parthenaic, paeanic, and dithyrambic song, and shifts from one to the other

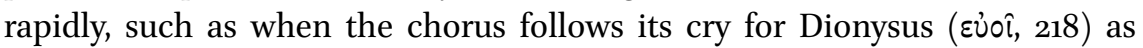

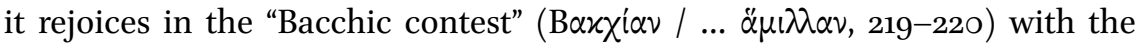

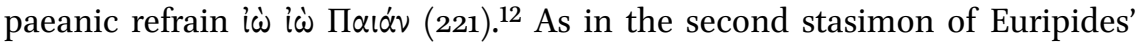
Heracles, there is a confusion of gender as well as genre here, since these maidens sing a paean, emphasizing this particular type of song above all; they mark this mix by beginning with the ritual cry of $\partial \lambda \circ \lambda \nu \gamma \dot{\eta}$, which is typically a female utterance, and ending with $i \omega i \dot{\omega} \Pi \alpha \alpha^{\alpha} \nu .^{13}$ In its ecstatic anticipation of Heracles' arrival the chorus thus transforms itself into multiple performers of multiple songs. Also as in Euripides' ode, however, the extreme nature of its genre (and gender) mixing here adds an unsettling note to their performance, so that, while the audience is encouraged to feel similar excitement through such mousike, it may also have a premonition of the inevitable reversal that is soon to come. Thus it is not simply the prematurely exuberant tone of the song that heralds a tragic reversal, causing it to be a so-called "joy-beforedisaster ode," but the vertiginous overload of different song types combined within it. ${ }^{14}$

The mix of genres in this performance allows the chorus to call on multiple divine participants to join its choreia in celebration of Heracles' returnApollo, Artemis, the nymphs, and Dionysus, who becomes synonymous with

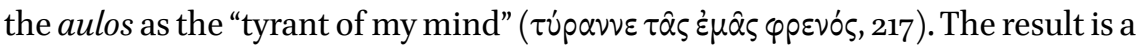
sense of multiple epiphanies, culminating in the chorus' direction to Deianeira to "look, look" (" $\delta \varepsilon \varepsilon$ " $\delta$ ', 222) and see "these things" ( $\tau \dot{\alpha} \delta$ ', 223) before her, so that the divine epiphanies generated through its choreia culminate in what we expect to be Heracles' own long-awaited appearance. Instead, however, a procession of captives enters, and the hero's own triumphant epiphany can only be imagined musically by the chorus, as it is again four hundred lines later:

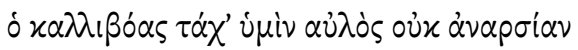

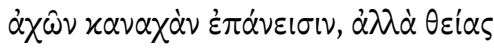

$\alpha \nu \tau i \lambda u p o v \mu \circ v^{\prime} \sigma \alpha \varsigma$.

12 Henrichs 1994-1995: 79-84; Power 2012: 293-295. Cf. Rutherford 1994-1995: 120; Battezzato 2005a: 163 .

13 On these gender divisions, see Henrichs 1994-1995: 104-105, n. 99.

14 On the device of "premature choral jubilation" here, see esp. Henrichs 1994-1995: 7984 . 
Soon the beautiful shout of the aulos will rise up for you again, not sounding out an unharmonious clamor, but [the sound of] divine music, responding to the lyre.

sорн. Trach. 640-642

When Heracles does finally come on stage, however, the chorus' mousike is markedly different. In contrast to its earlier jubilant and multi-genre, multigod performance, now, as the dying hero is carried in, the chorus sings a lament, marking it as such by comparing its song to the "shrill-voiced nightingale" ( $\partial \xi \dot{v}$ $\varphi \omega \nu \circ \varsigma \dot{\omega} \varsigma \dot{\alpha} \dot{\delta} \dot{\omega} v, 963)$, the archetypal figure of mourning. Soon, however, as in Euripides' tragedy, the chorus ceases singing altogether. First it breaks off its lament as it turns to look at the long-awaited Heracles, and focuses on the silence of his entrance instead: the steps of those carrying him are "noiseless"

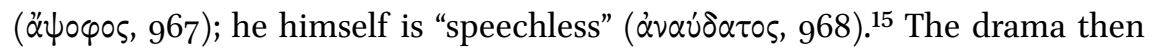
centers on Heracles' own painful singing, followed by the intimate exchange between him and his son. This shift away from the chorus' song and dance, with its inclusion of multiple forms of choreia, stresses the poignant contrast between the public, divine celebration that it previously envisaged and the reality of Heracles' fate.

\section{Moving on from Lament: Euripides' Helen and Iphigenia in Tauris}

In Heracles and Trachiniae, then, we see the dramatic effects of multiple lyric forms giving way first to lament and then to choral silence. Two tragedies by Euripides, Helen and Iphigenia in Tauris, demonstrate the opposite choral structure, whereby an important turning point in the dramatic narrative is marked by a shift from lament into other musical forms. These tragedies have remarkably similar plot structures: both begin with the plight of the central heroine in a barbarian land (Egypt, Tauris), then look toward a more positive outcome once she is reunited with a newly arrived Greek hero (Menelaus, Orestes), with whom she finally travels back to Greece. ${ }^{16}$ They also have very

\footnotetext{
15 Cf. Scott 1996: 15; Henrichs 1994-1995: 85 .

16 On the structural similarities between Helen and IT, see esp. Platnauer 1938: xv-vi; Matthiessen 1964; Mastronarde 2010: 73-74; Marshall 2014: 45-49. Based on these similarities, as well as what remains of Andromeda, Wright (2005: 43-55) has argued that they were all performed together as an "escape trilogy." This argument has rightly been met with some skepticism: Foley 2006; Gregory 2006; Kyriakou 2006; Marshall 2009, 2014: 12.
} 
similar musical narratives, beginning with an antiphonal lament sung by the heroine and her chorus, then transitioning to other types of song as she prepares for her escape.

This is not to say that the laments performed early on in Helen are themselves a "pure" generic form. On the contrary, the parodos that Helen sings with the chorus, though she frames it as one of mourning, asking "what sort of lament should I strive for or what music should I follow, with tears or dirges

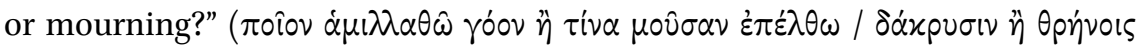
ทे $\pi \varepsilon \dot{\varepsilon} \theta \varepsilon \sigma v$; Hel. 165-166), incorporates parthenaic and paeanic elements as well: she addresses the chorus as Sirens, archetypal parthenaic singers (and ones with strong funereal associations), calling them "winged maidens, virgin

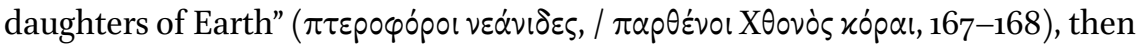

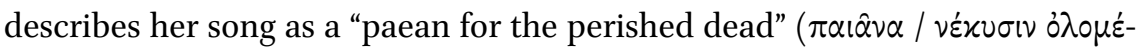
vol5, 177-178). ${ }^{17}$ The chorus in turn portrays Helen as a parthenos or new bride (nymphe) by describing her cry as that of a Naiad nymph (184-190). ${ }^{18}$ Nevertheless, lament remains the dominant genre at play not just in this song, but also in Helen's next lyric exchange with the chorus $\left(33^{0}-385\right)$ and in the long-delayed first stasimon (1106-1164).

The transition from lament to other song types in Helen begins with the socalled "Great Mother Ode," in which the chorus describes the frantic search of Cybele for her daughter, Kore. In the second strophe of this ode it sings of how Zeus finally consoled the goddess by means of a musical performance that is very different from those previously evoked in the play:

$$
\begin{aligned}
& \text { हं } \pi \varepsilon i \delta^{\prime} \text { ' है } \pi \alpha \nu \sigma^{\prime} \varepsilon i \lambda \alpha \pi i \nu \alpha \varsigma
\end{aligned}
$$

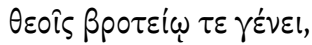

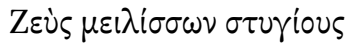

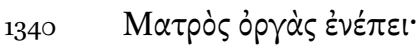

17 On paeans in chthonic contexts, see Rutherford 1994-1995: 119-124, 2001: 118-120; also Swift 2010: 71-72. Rutherford stresses, contra Kannicht 1969: 2. 70, that the chthonic $\pi \alpha \hat{\alpha} v \alpha$ in Hel. 177 is not simply an oxymoron, but that the song itself is a "generic hybrid" (19941995: 124). Ford (2010: 290-294) suggests that, like the description of the nightingale's song in Ar. $A v \cdot 209-222$, the transformation of Helen's song from a solo cry into a choral paean to the dead shows "a solitary outpouring of sorrow being sublimated into a fundamentally different kind of song” (293), marking Helen's own transformation from individual mourner into chorus leader.

18 As many have noted, the chorus' description of their clothes-washing also recalls the account of the companions of Nausicaa, a maiden on the point of marriage, in the Odyssey (6.85-109): see Foley 2001: 306 n. 10; Burian 2007: 10-11; Ford 2010: 294; Murnaghan 2013: 174. On the parthenaic motifs in this song, see also Swift 2010: 225-226. 


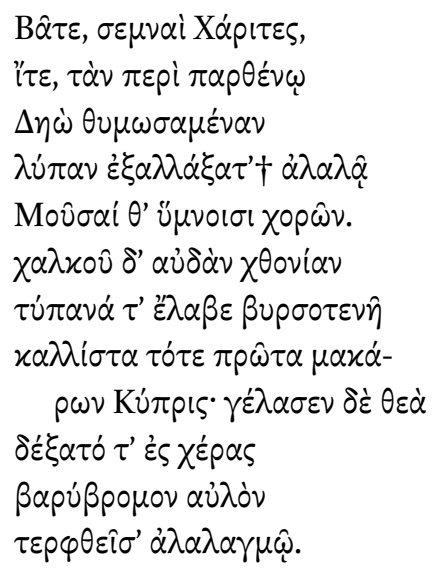

But when she stopped feasts for gods and the mortal race, Zeus, trying to soothe the grim wrath of the Mother, says, "Step forth, holy Graces, go, and take Deo, who is angered for her daughter, away from her griefs with the cry of alala, and you, Muses, with the songs of choruses." And the earthy voice of bronze and the drums of stretched hide then for the first time Cypris, loveliest of the blessed ones, took up; and the goddess laughed and took into her hands the deep-roaring aulos, delighting in the alala cry.

EUR. Hel. $1337-135^{2}$

This story of how song, dance, and instrumental music achieved the appeasement of the Great Mother provides an aetiology for the instruments and choral performances associated with her cult, which is syncretized with the rites of both Demeter and Dionysus: ${ }^{19}$ here the choruses cry alala, Aphrodite takes up the cymbals ("the earthy voice of bronze") and drum (tympanon), and the Great Mother delights in the aulos; earlier in the ode, as the goddess searches for her daughter, the chorus sings of the "roaring castanets (krotala), sending forth

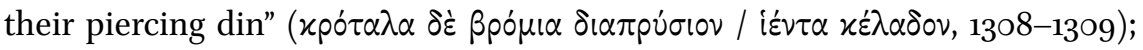
in the final antistrophe it refers to the "whirling, circular shaking of the rhom-

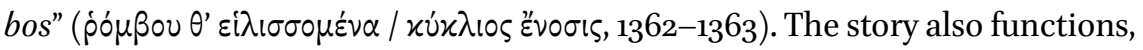
however, as a sort of aition for the Dionysiac performance of Athenian citizens in the orchestra, singing and dancing to the tune of the aulos that causes the goddess so much delight. The ode thus tracks—even enacts—-the transition

19 On the syncretism of the Great Mother, Demeter, and Dionysus, see Parker 1996: 188-189, 2005: 344-345; Roller 1996: 312-313, 1999: 174-176; Allan 2004: 143-146, 2008: 29; Currie 2005: 394-396; D’Alessio 2013: 130-131; Battezzato 2013: 106; Prauscello 2013: 78. 
from lament to the beginnings of Dionysiac mousike, including the mousike of the theater itself. ${ }^{20}$ This generic shift simultaneously mirrors the movement of the plot: now, as Helen and Menelaus put into action their plan to escape from Egypt back to Greece, the chorus abandons its mourning songs and looks forward to Helen's resumption of cultic mousike in Sparta, which it describes and performs itself in the following stasimon. ${ }^{21}$

In Iphigenia in Tauris the initial dominance of responsive lament contrasts sharply with the chorus' third and final stasimon, a hymn to Apollo (12341282). We are primed early on in the play to notice the difference, when, singing the parodos responsively with Iphigenia, the chorus highlights the contrast between laments and paeans:

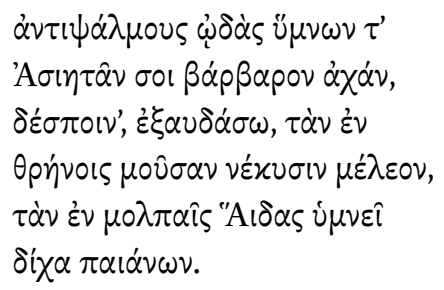

Antiphonal songs and barbarian cry of Asian songs I shall shout out to you, mistress, the music in dirges for the dead, wretched, which Hades hymns in songs, remote from paeans.

EUR. IT 179-185

Lament in tragedy is typically characterized by what it is not: Iphigenia has just

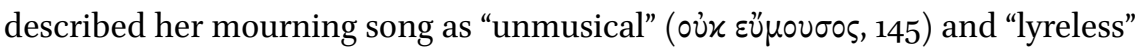
( $\alpha^{2} \lambda$ upos, 146). ${ }^{22}$ Here the chorus again highlights the apparent absence of musicality in its performance as well as its sombre tone by calling it "remote from paeans" ( $\delta \dot{\chi} \chi \alpha \alpha \alpha i \alpha \dot{v} \omega \nu, 185)$. But its final ode, though often labeled "dithyrambic" on account of its mythical narrative, is more (or also) reminiscent of a paean: ${ }^{23}$

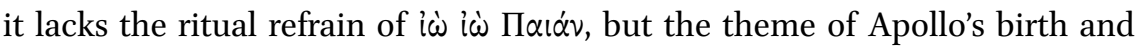
aetiology of his seat at Delphi is a common paeanic one. ${ }^{24}$ This musical shift

$20 \quad$ Ford 2010 argues that the play enacts a "genealogy of song," tracing it back to "the inarticulate grieving of abandoned women" (285). Cf. Murnaghan 2013; Steiner 2013: 177-181.

21 For a fuller discussion of the musical structure of Helen, see Weiss 2018: 140-19o.

22 On the characterization of lament as "unmusical" in tragedy, see Segal 1993: 16-20; Wilson 1999-200o: 433-439; Loraux 2002: 54-65; Weiss 2017.

23 On this ode as "dithyrambic," see esp. Panagl 1971: 119-132; Cropp 20oo: 247; Kyriakou 20o6: 391.

The dactylo-epitrite rhythm is also common to several extant paeans, though in general 
marks the dramatic one, as Iphigenia, having successfully tricked Thoas into letting her carry out a purification ceremony in the sea, has gone with Orestes and Pylades to their ship. Yet the change in music, suggesting a quick, positive resolution to the plot, also somewhat misleads us, so that the messenger's report that follows comes as more of a surprise: even the singing of paeans (1403-1404) failed to prevent the ship from being driven back to land. Iphigenia, Orestes, and Pylades do eventually escape, but only thanks to Athena's intervention.

Between the lament at the start of Iphigenia in Tauris and the paean at its end comes a variety of different song types, as we would expect, and such mixing of lyric genres relates directly to the themes and action of the play. In the second stasimon, for example, the chorus begins with a lament for its own abandonment, likening its singing to that of the mourning halcyon bird: "I compare

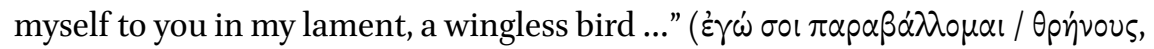

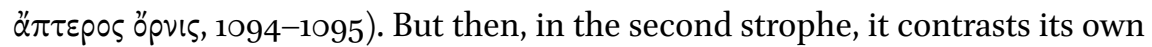
journey to Tauris on a slave ship with a vivid description of Iphigenia's escape back to Greece on a fifty-oared ship, accompanied by Pan with his syrinx and Apollo with his lyre:

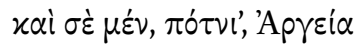 \\ $\pi \varepsilon v \tau \eta x o ́ v \tau \varepsilon p o s$ oix

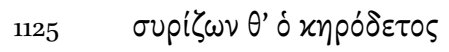 \\ Паvòs oủpzíov xá̀ $\alpha \mu \circ$ \\ $\chi \omega^{\prime} \pi \alpha \iota \varsigma \dot{\varepsilon} \pi \imath \omega \dot{u}^{\prime} \xi \varepsilon$,

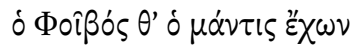

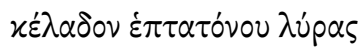 \\ ${ }_{1130} \dot{\alpha} \varepsilon \dot{\delta} \delta \omega \nu \grave{\alpha} \xi \varepsilon 1 \lambda \iota \pi \alpha \rho \dot{\alpha} \nu$

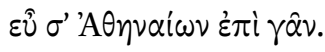 \\ $\dagger \hat{\varepsilon} \mu \dot{\varepsilon} \delta^{\prime} \alpha \dot{\tau} \tau 0 \hat{\nu} \lambda เ \pi \circ \hat{\sigma} \sigma \alpha$

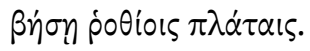

And you, lady, an Argive ship with fifty rowers shall bring home, and the wax-bound reed of Pan, the mountain god, will blow and shout out to the oars, while Phoebus the prophet, holding the noisy seven-stringed lyre, will sing and lead you safely to the gleaming land of Athens. $†$ But me you shall leave here and make your way with splashing oars ...

Eur. IT 1123-1133

surviving songs of this type display a wide range of meters: see Rutherford 2001: 78-79. On the narrative of Apollo's birth and establishment of the oracle at Delphi as a paeanic theme, see ibid: $74-75$. 
Previously in the first stasimon the chorus mentioned "choruses of fifty

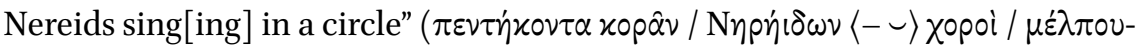
$\sigma \downarrow v \dot{\varepsilon} \gamma x \dot{u} x \lambda 101,427-429)$. In doing so, it evoked the dithyramb, which was danced by fifty choreuts in a circular formation to the accompaniment of the aulos, and with which Nereids are often associated in Greek literature and art. ${ }^{25}$ The dramatic chorus' own dancing (perhaps also circular) to the aulos in the orchestra, combined with its verbal description of the Nereids, would strengthen the suggestion of such a performance. ${ }^{26}$ Now it picks up on this generic allusion again with the image of the fifty-oared ship, which encourages the audience to link oars with dithyrambic dancers, though here dancing to the musical accompaniment of Pan with his syrinx and Apollo with his lyre rather than the aulos. As Barbara Kowalzig has demonstrated, the emphasis on musical, maritime travel is also characteristic of the dithyramb. ${ }^{27}$ The musical journey to Athens that the chorus envisages here looks forward to and proleptically enacts the voyage of Iphigenia, Orestes, and Pylades soon to occur offstage, even as, like the third stasimon, it elides the difficulties of their first attempt.

In the final antistrophe of the second stasimon the women evoke another lyric genre, this time partheneion. First they express the wish to fly like a bird (1138-1142), evoking the sort of avian imagery that we commonly find in parthenaic song, such as Alcman's first Partheneion. ${ }^{28}$ Then they explicitly confirm this generic echo when they imagine returning to the parthenaic choruses in which they once took part:

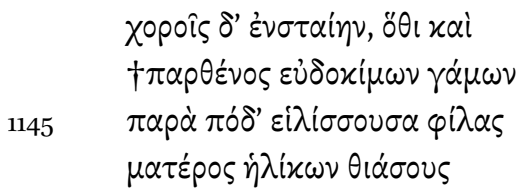

If only I could take my stand in choruses, where also †as a maiden at glorious weddings, whirling my foot alongside the bands of my dear mother's companions ...

EUR. IT $1143^{-1146}$

\footnotetext{
25 On the circular formation of the dithyramb, see D'Angour 1997. On the association of (fifty) Nereids with the dithyramb, see Csapo 2003.

26 On the overlap between such descriptions of mousike and the chorus' own performance, see Weiss 2018.

$27 \quad$ Kowalzig 2013.

28 Alcm. fr. $1 P M G$ 6o, 86. On avian imagery in partheneia, see Steiner forthcoming: ch. 3; Weiss 2018: 29-30.
} 
Though this wish expresses the loss of their former status as marriageable young girls in Greece, the chorus also briefly (re)enacts such choreia through its own song and dance, combined with its vivid description of its former movement. The parthenaic theme and performance here are thus folded into the maidens' lament for their current situation in Tauris. At the same time, however, this evocation of partheneia also encourages the audience to look forward to the chorus' own departure, separate from Iphigenia's, which Athena orders at the end of the tragedy.

\section{Genre and Audience Response}

The combinations and interactions of different genres in a tragedy therefore affect the audience's reception not just of an individual song, but of the dramatic narrative as a whole. Generic allusions are not-or at least need not be-merely discrete and temporary, confined to the one lyric performance without any bearing on the rest of the drama. ${ }^{29}$ On the contrary, as the above analysis of Sophocles' Trachiniae and Euripides' Heracles, Helen, and Iphigenia in Tauris has suggested, they can be intricately connected to the plot and be part of a larger musical pattern at play through the course of a tragedy. It is therefore worth pausing here to consider the process by which evocations of genre in choral lyric - verbal, musical, and/or choreographic — encourage the audience to anticipate an event or movement in the drama as a whole. Genre and audience response are closely tied together. If we apply Jauss' influential terms concerning the response of a reader to that of an audience in the theater, we might think of lyric genres, especially as they are deployed in tragedy, as "horizons of expectation," familiar to the audience from other performances, which are then "varied, corrected, altered, or even just reproduced" within a play. ${ }^{30}$ The ways in which these can guide a specific response from the audience can be similar, then, to how a text "awakens memories of that which was already read, brings the reader to a specific emotional attitude, and with its beginning arouses expectations for the 'middle and end,' which can then be maintained

29 Contra Swift 2010: 72 on the paean: "[ $\mathrm{t}]$ he genre is evoked in order to create a moment of tension or irony; once over, the allusion is no longer relevant, and we are not meant to keep it in mind later during the play."

30 Jauss 1982: 23. On genre as a set or system of expectations, dependent on the reader's (and author's) own generic repertoire, see also esp. Culler 1975: 113-130; Dubrow 1982; Fowler 1982; Todorov 1990. 
intact or altered, reoriented, or even fulfilled ironically in the course of the reading according to specific rules of the genre or type of text."31

The original audiences of classical tragedy would, we can imagine, be especially receptive to evocations of particular types of song, given their own experience of and participation in the "generic system" of song culture both within Attica and, in the case of visitors and metics, elsewhere in Greece. ${ }^{32}$ Many Athenian spectators would at some point have been musical performers themselves, both in and outside the theater, of at least some of the song types represented and included within any given tragedy: ${ }^{33}$ they may have sung and danced, for example, in one of the twenty dithyrambic choruses that performed yearly in Athens (involving a total of one thousand choreuts each year). Some genres might have been known to certain audience members from their experience of being spectators of choreia more than performers, and through their familiarity with allusions to particular forms of song not just in previous plays (tragic, satyric, and comic) but in other media as well, such as inscribed paeans or vase paintings depicting parthenaic or Dionysiac mousike.

The nature of the audience's previous engagement with various lyric genres within and outside the theater suggests that the performance of choreia in tragedy could go beyond Jauss' textual model in its ability to direct an audience's response. As Sarah Olsen demonstrates in this volume, choreia could work on the audience physically, activating its somatic memory (or "embodied cultural knowledge") of a song type as a past performer and/or spectator. ${ }^{34}$ This is memory of particular emotions combined with bodily and sensorial participation - the ecstasy of Dionysiac ritual, for example, or the grief and pity of lament. ${ }^{35}$ When the audience of a tragedy would hear (and see) a turn toward a Dionysiac or paeanic song instead of a lament, or, conversely, the hint of a lament amid more celebratory mousike, it would therefore not only be primed to notice that turn but to feel and participate in it. The audience's response would include adjusting its expectations for the ensuing action within the drama: so when it experiences the new form of choreia in Helen, for instance, it can begin to look toward the plot's happy resolution. Often, of course, the per-

\footnotetext{
31 Jauss 1982: 23 .

32 On ancient Greek "song culture" and its connection to Athenian audiences' experiences of tragedy, see Herington 1985: 3-5; Bacon 1994-1995; Revermann 2006. Cf. Revermann 2006 on the "competence" of audiences of tragedy in fifth-century Athens; also Gagné and Hopman 2013a: 26; Peponi 2013a: 212-213.

34 Olsen takes the term "embodied cultural knowledge" from Sklar 2008. Cf. Olsen 2017 on kinesthetic empathy in choreia; also Weiss 2018: 235-241. Cf. Estrin (this volume) on genre as a "structure of feeling."
} 
formance of a particular song type in a tragedy cannot be taken entirely at such face value, as we saw in the case of the evocations of the dithyramb and paean in Iphigenia in Tauris. A more extreme example is the jubilant first stasimon of Sophocles' Trachiniae that I discussed above: the audience knows of Heracles' imminent fate but must to some degree be carried along with and brought into the performance of ecstatic choreia, which prompts it to hope for an outcome (and a form of epiphany) that it realizes will be impossible.

\title{
The Hybridity of Tragic Song: Euripides' Troades
}

The combination of multiple genres within one song, like the first stasimon of Trachiniae, can also shape the audience's expectations for what tragedy itself is and can be. As we have seen in this tragedy and also in Heracles and Iphigenia in Tauris, different lyric genres can be so intertwined with or embedded within one another that it is often hard to distinguish them. Even in a play where one genre does seem to dominate - and in tragedy, that genre is often lament - we can find a complex generic hybridity within a single song.

Such a mix of generic consistency and hybridity is especially pronounced in Euripides' Troades. Lament pervades this tragedy: it opens and closes with the antiphonal mourning of Hecuba and the chorus, and sung lament repeatedly interrupts spoken dialogue throughout. ${ }^{36}$ But the first stasimon, in which the chorus sings of the night the Trojans brought the horse within their walls, is rather different, combining an extraordinary array of musical genres. It begins with an evocation of epic:

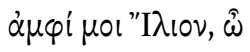

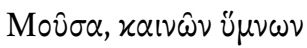

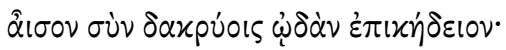

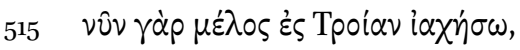

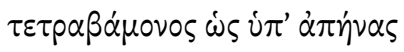

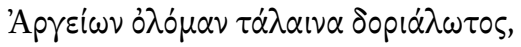

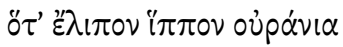

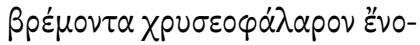

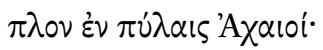 \\ $\alpha \nu \dot{\alpha} \delta^{\prime} \dot{\varepsilon} \beta \dot{\alpha} \alpha \sigma \varepsilon \nu \lambda \varepsilon \dot{\omega} \varsigma$

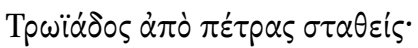

36 On lament in Troades, see Suter 2003; Weiss 2018: 100-139. 
"I $\tau^{\prime}, \hat{\omega} \pi \varepsilon \pi \alpha \nu \mu \varepsilon \varepsilon^{\prime} \circ \mathrm{l} \pi \sigma^{\prime} \nu \omega \nu$,

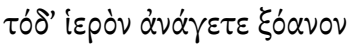

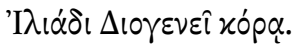

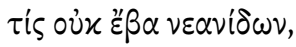

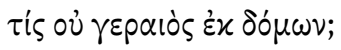

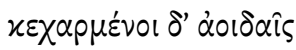

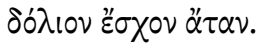

About Troy, O Muse, sing for me a funeral ode of new songs, with tears: for now I will cry out a song to Troy, telling how as a result of a four-footed vehicle I was ruined, [becoming] the Argives' wretched captive, when the Achaeans left at our gates the horse, making a rumbling noise up to the sky, with its trappings of gold and armed [within]; and the people shouted out from the Trojan rock, standing there, "Go, you who have ceased from toils, bring this holy image to [the shrine of] the Zeus-born maiden of Troy!" Who of the young women didn't come, what old man didn't [come] from his house? Rejoicing with songs they received treacherous ruin. EUR. Tro. ${ }^{11-530}$

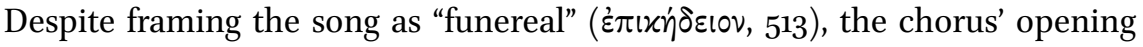
address to the Muse is instead typical of epic and the Homeric hymns. ${ }^{37}$ Within the first three lines some dactylic rhythms also creep in, creating a sense of the tragic appropriation of epic and hymnic style. Yet this evocation of epic is by no means uniform or fixed, as the chorus' proclamation of "new songs" ( $x \alpha \downarrow \omega \omega \nu$ $u \mu \nu \omega \nu, 512$ ) suggests: we have here not only a surprising mix of epic and lament, but also a song delivered from a first-person, female perspective, thus further deviating from traditional epic treatments of Troy's fall. Other lyric genres are present too: Wilamowitz suggested that the ode's opening phrase ( $\alpha \mu \varphi^{\prime}\left(\mu \circ, 5^{11}\right)$ evokes a kitharodic proimion; several scholars have argued that the rare com-

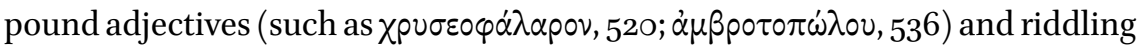

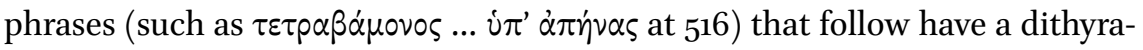
mbic flavor. ${ }^{38}$

37 Cf. esp. Hom. Hymn 19.1, 20.1, 33.1; this use of $\alpha \mu \varphi$ i with the accusative of a song's subject also occurs at Hom. Hymn 7.1, 22.1. On the novelty of this epic address within tragic lyric, see Neitzel 1967: 44; Lee 1976: 164; Hose 1991: 303; Quijada 2006: 844; D’Angour 2011: 194. On further parallels between the Troades first stasimon and the Iliad, see Sansone 2009 . Torrance (2013: 219-228) argues that the "new songs" denote a new version of Demodocus' song about the wooden horse and destruction of Troy (Od. 8.426-534).

38 On the ode's "dithyrambic" language, see Wilamowitz 1921: 174; Neitzel 1967: 45; Battezzato 2005b: 17. Cf. Kranz 1933: 243. 
Such rich mixing of genres continues through the rest of the ode. In the final lines we can detect a trace of epinician, when, in a horrible distortion of a victory song, the women claim that the bloodshed at Troy has produced a child-bearing garland $(\sigma \tau \varepsilon \dot{\varepsilon} \varphi \alpha \nu \vee v, 565)$ for Greece. At the ode's center we find partheneia, this time in the chorus' description of its own choreia on the night of Troy's destruction:

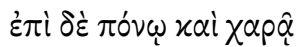

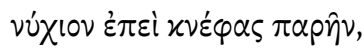

$$
\begin{aligned}
& \Lambda i ß u \varsigma \tau \varepsilon \lambda \omega \tau \dot{\jmath} \varsigma \dot{\varepsilon} \varkappa \tau \dot{\tau} \pi \varepsilon l \\
& 545 \Phi \rho u ́ \gamma \mid \alpha ́ \alpha \varepsilon \mu \dot{\varepsilon} \lambda \varepsilon \alpha, \pi \alpha \rho \theta \varepsilon \varepsilon^{\prime} 01 \delta^{\prime}
\end{aligned}
$$

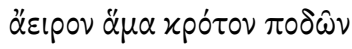

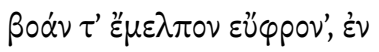

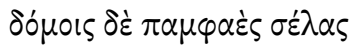

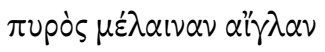

$$
\begin{aligned}
& 550 \dagger \varepsilon ้ \delta \omega x \varepsilon v \ddot{v} \pi \nu \omega \dagger \dagger \text {. } \\
& \varepsilon \dot{\varepsilon} \gamma \dot{\omega} \delta \dot{\varepsilon} \tau \dot{\alpha} \nu \text { ỏp } \sigma \tau \tau \varepsilon \dot{\varepsilon} \rho \alpha \nu
\end{aligned}
$$

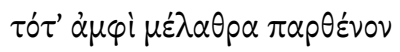

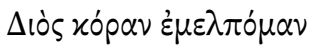

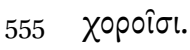

And nighttime darkness came upon their toil and joy, and when the Libyan lotos pipe was sounding as well as Phrygian songs, and maidens raised together the beat of their feet and sang and danced a cheerful cry, and in the halls an all-blazing gleam of fire †shed a dark glow on sleep. $\dagger$

And I to the mountain maiden, the daughter of Zeus, around the halls I was singing and dancing then in choruses.

EUR. Tro. $544-547$

This is more than a verbal signpost toward the parthenaic genre: the chorus

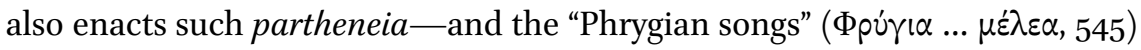
more broadly — through its own song and dance to the accompaniment of the aulos, to which the "Libyan lotos pipe" ( $\Lambda$ iß $\cup$... $\lambda \omega \tau$ ós, 544) refers.

The question of what exactly are the "new songs" that the chorus announces at the start of the first stasimon has been much debated. Luigi Battezzato, in his nuanced reading of this ode, has argued that it enacts the Greeks' victory over the Trojans by replacing the women's Phrygian mousike with distinctively 
Greek forms. ${ }^{39}$ Given the chorus' return (with Hecuba) to lament later in the play, and given the extreme mixing of genres throughout the ode, I do not think that such a replacement of one form of mousike for another is quite as evident as he suggests. Nevertheless, the combination of epic, hymnic, kitharodic, dithyrambic, epinician, and parthenaic elements here does point to the beginnings of these "new" song types in the wake of Troy's fall. Indeed, the idea that such songs have their roots here recurs later in the tragedy, when Hecuba remarks that the Trojan women's sufferings will provide "songs for the music of

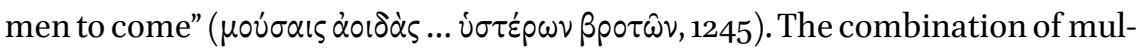
tiple genres in the first stasimon also points to the hybridity of tragedy itself, creating a musical aetiology for the very performance being produced there in the Theater of Dionysus out of Troy's destruction. As in Helen, then, the mousike of the theater is here fashioned out of lament. The "new songs" heralded by the chorus refer to the total amalgam of different lyric forms presented within this ode-an especially pronounced version of a typical tragic trait.

\section{Musical Innovation and the Myth of Generic Purity}

It is tempting to view songs like this one in Euripides' Troades in the light of a famous passage in Plato's Laws, in which the confusion of musical genres appears to be linked to the "New Music" - that is, to the period of musical innovation in the fifth and early fourth centuries BCE that has come to dominate many modern discussions of Greek mousike. ${ }^{40}$ In Book 2 the Athenian

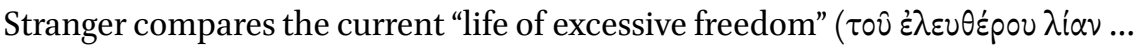

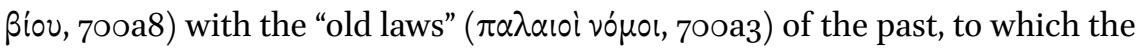
demos strictly adhered:

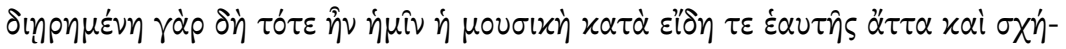

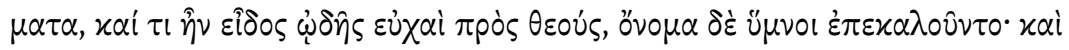

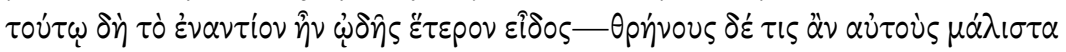

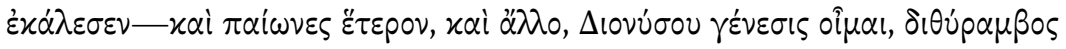

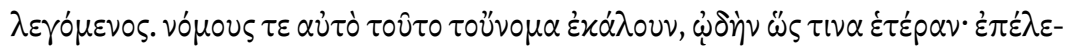

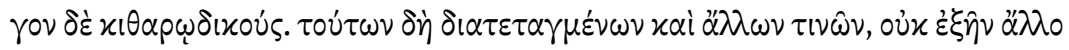

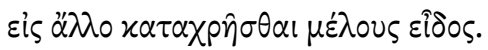

39 Battezzato 2005b.

40 See e.g. Csapo 1999-200o, 2004; D’Angour 2006, 2007. 
For at that time among us mousike was divided according to its various forms and styles, and one form of song was prayers to gods, and they were called "hymns"; and, in contrast to this, there was another form of songone would have best called them "dirges" — and another [called] "paeans," and another, I think originating from Dionysus, called "dithyramb." They used to call one particular one "nomes," as another [type of] song; and they called them in addition "kitharodic." Since these and other types were categorized, it was not possible to misapply one form of song to another.

PL. Leg. 700a9-c1

According to this narrative, the strict separation of different lyric genres later gave way to a licentious blurring of categories that is, the Athenian claims,

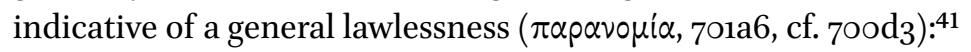

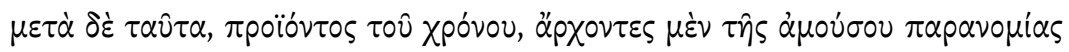

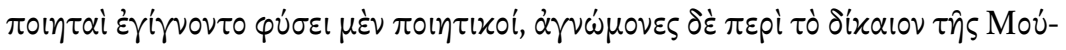

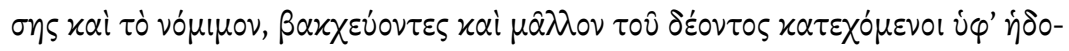

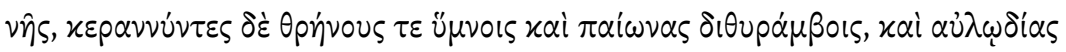

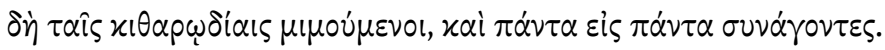

But afterwards, as time went on, there arose leaders of unmusical lawlessness, poets who, though by nature poetical, were ignorant about what is just and lawful in music, being full of Bacchic frenzy and possessed by pleasure more than is fitting, and they mixed both dirges with hymns and paeans with dithyrambs, and represented aulos songs with kithara songs, and brought together everything with everything.

PL. Leg. $700 \mathrm{~d} 2-\mathrm{e} 1$

Might we view Euripides, then, as one of these "leaders of unmusical lawless-

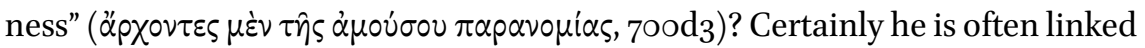
in modern scholarship to the "New Music," and one characteristic of this period of musical innovation may have been experimentation with the mixing of genres, as the Athenian Stranger here claims. And yet, as we have seen in the cases of Supplices and Trachiniae (both tragedies for which the date of production is much debated), Aeschylus and Sophocles also play with combining different lyric genres in their work. ${ }^{42}$

41 On this narrative and the myth of generic purity, see also the Introduction to this volume. 
Indeed, as Battezzato has noted, the parodos of Aeschylus' Agamemnon exhibits an especially complex degree of generic play, combining epic, kitharodic, paeanic, and epinician elements within one song. ${ }^{43}$ At one point, for example, the chorus seems to perform a paean, singing "I call on the healer Paean" (iท่ $\circ \nu \delta \dot{\varepsilon} \chi \alpha \lambda \dot{\varepsilon} \omega \omega \alpha \iota \hat{\alpha} \nu \alpha, 146)$. A few lines later it gives itself the performative direction "utter ailinon ailinon, but let the good win out" ( $\alpha_{i} \lambda$ ilvov $\alpha i \lambda$ ilvov $\varepsilon i \pi \dot{\varepsilon}, \tau \dot{\partial} \delta$ ' $\varepsilon \hat{\jmath} \nu(x \alpha \dot{\alpha} \tau \omega, 159)$; the combination of this ritual cry of lament following the chorus' account of Calchas' prophecy with the hopeful wish for better things to come demonstrates how closely the mix of song types here (lament and paean) is tied to the song's content and emotional impact. Later in the parodos the chorus evokes the paean again by remembering how Iphigenia used lovingly to sing such a song for her father in his banqueting halls (240-247). In doing so, it, like the chorus of Troades, enacts this paean through its own performance, so that this scene of the past, which contrasts so painfully with the present of the dramatic narrative, comes to life. Genres and genders are not just combined but subverted here, since, as I have already mentioned, performances of paeans outside tragedy were both choral and exclusively male. The embeddedness of this solo paean, sung by Iphigenia in her father's honor, within a choral ode performed by Argive men, is suggestive of how with her singular sacrifice she acts on behalf of the entire community, displacing the army as Greece's savior. At the same time, the men's voices envelop Iphigenia's,

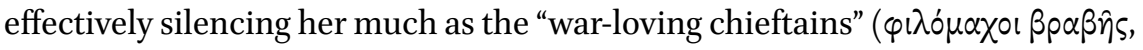
230) did when they disregarded her "pleas and cries of "Father" ( $\lambda ı \dot{\alpha} \varsigma$... xai $x \lambda \eta \delta$ óvas $\pi \alpha \tau p \dot{\omega}$ lous, 228) at the moment of her sacrifice. ${ }^{44}$

In his later plays Euripides may especially revel in mixing up genres, but we can see that this was not just a late fifth-century phenomenon, and indeed there is no suggestion in Plato's Laws that it was one. The Athenian Stranger does not give any precise indication of chronology when he complains about the gradual degeneracy in morals and music: he simply claims that the blurring of categories happened "afterwards, as time went on" ( $\mu \varepsilon \tau \dot{\alpha} \delta \dot{\varepsilon} \tau \alpha \hat{v} \tau \alpha, \pi \rho 0 i ̈ o ́ v \tau o \varsigma$

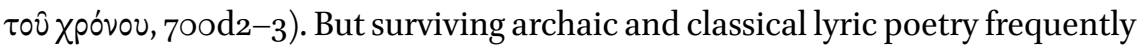
demonstrates how porous the distinction between different song types could

generally thought to be a late play, dated perhaps to the 46оs BCE: see esp. Garvie 1969 . On the date of Trachiniae, see esp. Easterling 1982: 19-23, with further bibliography (she concludes that any date between 457 and 430 is possible).

44 For a similar reading of the Agamemnon parodos, see Weiss 2018: 39-40. Euripides develops the motif of Iphigenia's paean at the end of Iphigenia in Aulis: see Weiss 2014 on Eur. IA 1475-1531; also Weiss 2018: 224-231. Wohl (1998: 77-78) interprets the silencing of Iphigenia in this scene as a violent enforcement of her virginity. 
be, thus undermining this diachronic narrative of generic purity giving way to laxity, as well as demonstrating that such experimentation was not necessarily recent. Bacchylides 17, for example, was marked as a dithyramb within the Alexandrian edition of his songs, but contains an invocation of Apollo at the end $(130-132)$ that seems strongly paeanic, and many scholars have debated to which genre(s) it therefore belongs. ${ }^{45}$ The generic reach of lyric poetry stretched beyond songs typically classified as "lyric" as well, as Sappho's appropriation of Homeric epic clearly demonstrates. Another later and especially hybrid example is Timotheus' Persians (fr. 791), a kitharodic nomos that also combines elements of paean, lament and dithyramb. Timotheus' display here may, like the declaration of "new songs" in Euripides' Troades, be an especially

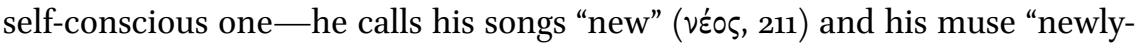
wrought" ( assume that the older lyric poets were any less self-aware in their use of multiple, overlapping genres. ${ }^{46}$

These examples also demonstrate that generic hybridity was by no means confined to the theater in archaic and classical Greece. The Athenian Stranger does seem to have theater especially in mind as the site for generic hybridityit led, he claims, to a "theatrocracy" ( $\theta \varepsilon \alpha \tau p o x p \alpha \tau i \alpha, 701 a 3)$ of noisy theatergoers. Yet he also describes this phenomenon as something which happened within each nondramatic song type: in contrast to their previously strict separation, now dirges, hymns, paeans, dithyrambs, aulos songs, and kithara songs were all mixed up with each other. Since the lyric genres from which the tragedians fashioned their own choreia were seldom themselves fixed, it is then no surprise that Aeschylus, Sophocles, and Euripides all experimented with the effects of combining different types of song.

Nevertheless, the idea that tragedy, in addition to nondramatic song types, was once generically "purer" is evident not just in Plato's Laws but also in the remark by Aristotle in his Poetics with which I began, when he refers to its dithyrambic origins. At work here seems to be the notion that tragedy came from one sort of choral song. We see this also in Euripides' Bacchae, a play

\footnotetext{
45 On the question of the genre of Bacchylides 17, see esp. Schmidt 1990; Zimmermann 1992: 91-93; Calame 2009a; Tsagalis 2009; D'Alessio 2013: 119-122. Cf. Foster in this volume on the "sequence of generically distinct songs" in Bacchylides 16.

46 On the dynamic play with genre already evident in archaic elegaic, iambic, and melic poetry, see esp. the Introduction to this volume and also the paper by Ford, both of which focus on Pind. fr. 128c SM. Cf. Farrell 2003: 389: "denying these poets an awareness about the instability of generic categories stems from nothing more than a misguided desire to believe that the practice of ancient poets was perfectly congruent with the (after all, rather primitive and simplistic) theories of ancient literary critics."
} 
which, for all its apparently "new musical" display, is in many respects most innovative in the archaizing nature of its mousike: not only does the chorus sing and dance for almost a quarter of the play-an amount of choreia unmatched by any other surviving Euripidean or Sophoclean tragedy—but its performance retains a strong Dionysiac flavor, and indeed at many points resembles a dithyramb. ${ }^{47}$ The chorus makes the connection between this particular type of choral song and its own performance especially clear when it

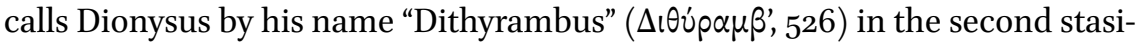
mon. Here, then, Euripides provides a sense of tragedy's aetiology not in terms of generic hybridity but by creating a play that consistently feels like a cult song for Dionysus-perhaps the sort of song from which tragedy as a whole was imagined to have developed.

The extraordinary (and surely deliberate) impression of generic consistency in the Bacchae, in contrast with the majority of our surviving tragedies, confirms that by the time of its production in $405 \mathrm{BCE}$ tragedy had for a long time been a hybrid genre. Using Bakhtin's terminology, we might then view tragedy itself as a "secondary genre," formed through the combination, assimilation, and transformation of various nondramatic genres of choral lyric. ${ }^{48}$ But given the capacious and flexible nature of the generic character of different forms of nondramatic choral lyric, it is problematic to view these in turn as "primary" or "simple," so in the end it is perhaps more helpful still to think of tragedy as a "super-genre" instead. There seem to have been few (if any) limits set on the range of choral lyric that tragedy could include within a performance, and indeed in a song like the first stasimon of Troades Euripides gives the impression of drawing on almost every sort of lyric category of which we, as a modern audience, are aware. Certainly for its original Athenian audience allusions to other types of song would have been apparent as well-after all, this is the poet who, according to the character of Aeschylus in Aristophanes' Frogs, "takes material from everything: from whore songs, drinking songs by Meletus, Car-

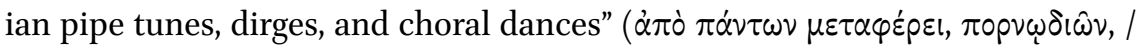

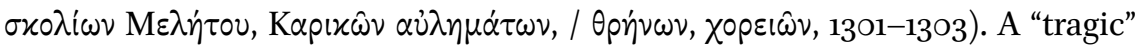
song can, it seems, be almost anything in terms of the forms and styles it includes, evokes, appropriates, and combines. In the end, what makes it "tragic" is its incorporation within a tragedy. If we believe Aristotle in the Poetics, the

47 On the Bacchae as dithyrambic and "new musical," see esp. Zimmermann 1992: 134; Csapo 1999-200o: 426. Battezzato (2005a: 163-164) also notes the remarkable generic consistency of Bacchae, especially in the parodos. On the mix of traditional and innovative mousike at work in the play, see Weiss 2018: 241-245. 
choral songs in tragedy became increasingly irrelevant to the plot, "thrown in" as embolima regardless of their context (1456a27-31) —in which case, at least in those plays surviving from the late 40os, we might expect to be able simply to remove such songs as distinct and generically classifiable without affecting the surrounding drama. But the extant fifth-century tragedies, even Euripides' latest plays, suggest that what also makes a song "tragic" is its deep connection to the dramatic narrative, in large part as a result of the different generic strands at work, their complex interactions with each other, and their resonances for the audience. 